\title{
REPELLENT ACTIVITY OF ESSENTIAL OILS FROM NATIVE PLANTS AND THEIR BLEND FOR Tribolium castaneum CONTROL IN STORE GRAINS
}

\section{ACTIVIDAD REPELENTE DE ACEITES ESENCIALES DE PLANTAS NATIVAS Y SU MEZCLA PARA CONTROLAR Tribolium castaneum EN GRANOS ALMACENADOS}

\author{
Saran Anabel ${ }^{1}$, Lucia Fernández ${ }^{1 *}$, Marisol Minig ${ }^{2}$ \\ Monica Bellozas Reinhard ${ }^{2}$ y Luciano Jose Merini ${ }^{1}$
}

Recibido 26/02/2019

Aceptado 23/05/2019

\begin{abstract}
The essential oils (EOs) from 5 native aromatic plants from La Pampa, Argentina, were obtained by hydrodistillation and tested for repellency on Tribolium castaneum Herbst. adults. All tested EOs showed high repellency activity at the highest concentration established $\left(0.3 \mathrm{mg} . \mathrm{cm}^{-2}\right)$. The EOs from Baccharis spartioides and Helianthus petiolaris were the most efficient, showing higher repellency when compared to the standard positive control (DEET). At $3 \times 10^{-1} \mathrm{mg}^{-\mathrm{cm}^{-2}}$, B. spartioides and H. petiolaris showed $95 \%$ and $92.2 \%$ of repellency respectively. The EOs chemical composition was then analyzed by Gas chromatography-mass spectrometry (GC-MS) and the first report of $H$. petiolaris EO composition is presented. Finally, in order to assess repellency activity in simulated "field conditions", pest behavior was evaluated in treated flour. In presence of $H$. petiolaris $\mathrm{EO}, 90 \%$ of the insects left the grain, while $B$. spartioides induced an $81 \%$ of emigration. To maximize the yields in repellent production, a blend using commercial lemon EO was proposed. The results obtained show a significant difference after $24 \mathrm{~h}$ of treatment, were the repellency of the blend persisted in contrast with pure EOs. These findings present the $B$. spartioides and $H$. petiolaris EOs blends as promising alternatives to control $T$. castaneum in stored grains.
\end{abstract}

KEY WORDS: essential oils, Tribolium castaneum, pest control, postharvest store

\section{RESUMEN}

Los aceites esenciales (EO) de 5 plantas aromáticas nativas de La Pampa, Argentina, se obtuvieron mediante hidrodestilación y se analizaron para determinar su repelencia en adultos de Tribolium casteneum Herbst. Todos los EO probados mostraron una alta actividad de repelencia a la concentración más alta establecida $\left(0.3 \mathrm{mg} . \mathrm{cm}^{-2}\right)$. Los EO de Baccharis spartioides y Helianthus petiolaris fueron los más eficientes, mostrando una mayor repelencia en comparación con el control positivo estándar (DEET). A $3 \times 10^{-1} \mathrm{mg}_{\mathrm{cm}} \mathrm{cm}^{-2}$, B. spartioides y $\mathrm{H}$. petiolaris mostraron un $95 \%$ y un $92,2 \%$ de repelencia, respectivamente. La composición química de los EO se analizó luego por cromatografía de gases-espectrometría de masas (GC-MS), se presenta la primera determinación de la composición química del EO de H. petiolaris. Finalmente, para evaluar la actividad de repelencia en "condiciones de campo" simuladas, se evaluó el comportamiento de la plaga en harina tratada. En presencia de EO $H$. petiolaris, el $90 \%$ de los insectos abandonaron el grano, mientras que $B$. spartioides indujo un $81 \%$ de emigración. Para maximizar los rendimientos en la producción de repelentes, se propuso una mezcla que utiliza EO limón comercial. Los resultados obtenidos muestran una diferencia significativa después de $24 \mathrm{~h}$ de tratamiento, donde la repelencia de la mezcla persistió en contraste con los EO puros. Estos hallazgos presentan las mezclas de EOs de $B$. spartioides y $H$. petiolaris como alternativas prometedoras para controlar $T$. castaneum en granos almacenados.

PalABRAS CLAVE: aceites esenciales, Tribolium castaneum, control de plagas, almacenamiento postcosecha

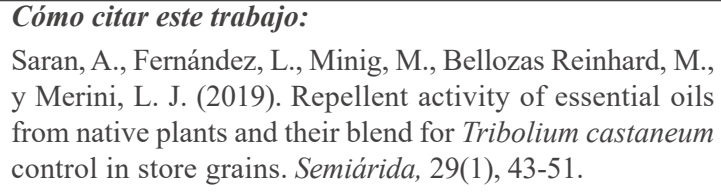

Saran, A., Fernández, L., Minig, M., Bellozas Reinhard, M., y Merini, L. J. (2019). Repellent activity of essential oils from native plants and their blend for Tribolium castaneum control in store grains. Semiárida, 29(1), 43-51.

\section{INTRODUCTION}

A large portion of tropical African, Asian and Latin American lands are under a unimodal and often highly variable rainfall pattern. Without

1 National Institute of Agricultural Technology, EEA Anguil, La Pampa, Argentina.

2 National University of La Pampa, Exact and Natural Sciences Faculty, La Pampa, Argentina.

* Fernandez lucia@inta.gob.ar 
irrigation systems, their local production is limited to one annual harvest and grains must be frequently stored for long periods in low tech deposits in small farms (Alonso Amelot \& Avila Núñez, 2011). In this context, there is a continuous need of protecting the stored grains against deterioration, especially from loss in quality and weight during the post-harvest way from field to consumer (Padin et al., 2002).

In Argentina, the post-harvest losses recorded for the main crops oscillating around $8 \%$, which generates approximately an economic loss of 1,000 million dollars per crop (INTA, 2008).

Tribolium castaneum Herbst., is one of the most widespread destructive primary pest of stored grains and it has been found as one of the most prevalent in harbor areas of Buenos Aires, Argentina (Descamps et al., 2008). Beetles and larvae feed on a wide variety of dry vegetable substances, such as milled cereal products, causing extensive loss in both quality and quantity of the stored product (Rees, 2004).

From decades, various types of fumigants and synthetic insecticides have been used for the control of insects in stored grain, but its frequently used has induced resistance in most of the pest strains (Subramanyam \& Hagstrum, 1995). Furthermore, the levels of acceptable pesticide residues in grains and oilseed (FAO, 2013; SENASA, 2013) limit the doses and the use of these fumigants, putting the pest control in a crossroads.

Recently, secondary plant metabolites have been intensively explored as an attempts to develop new bio rational alternatives. Such alternatives are expected to be pest specific, with low mammalian toxicity, easy to use, readily biodegradable and reduced in health and environmental impacts, in order to minimize the excessive reliance on the chemical pesticides (Jindal et al., 2013).

Volatile compounds produced by higher plants are responsible for plant to plant interaction, defense mechanism and for attracting pollinators (Batish et al., 2008). These volatile compounds (EO) have also shown insecticidal and repellent activity against stored grain insect pests (Bakkali et al., 2008). On the other hand, since botanicals pesticides have multiple mechanisms and sites of action, development of resistance is limited and needs long periods and large population for selection to occur (Regnault Roger et al., 2012). Although, its high volatility makes it necessary the formulation in order to increase its effectiveness, and that the concentrations in which they must be used are usually high, botanical insecticides have gained popularity in both, the integrated pest management and the agro-ecological production. As an example, Citrus EOs obtained as byproducts of the citrus processing have gained acceptance in the food industry since they have been recognized as safe, and many crops tolerate their presence (Fisher \& Phillips, 2008).

The main botanicals families from which EOs are extracted are Asteraceae, Myrtaceae, Lauraceae and Lamiaceae (Giuliano, 2001). Asteraceae (Asteraceae) family, also called "compound" (Compositae Giseke, cons. Name), gather more than 23.500 species, spread over some 1.600 genera, which is why they are the Angiosperm family with the greatest richness and biological diversity (Jeffrey, 2007). Asteraceae is the most numerous family in Argentina, with 227 genera (five are endemic) and 1400 species (92 are adventitious and 382 are endemic). There are Asteraceae in most of the biomes, which adapt to different soils, climates and reliefs. In the phytogeographic province of Puna, the Asteraceae have adapted to water deficit, low atmospheric humidity, high solar radiation and nocturnal temperatures below zero throughout the year. The most represented tribe in number of genera is Heliantheae and in number of species the tribe Senecioneae. In the province of La Pampa this family is the second most important after Poaseae (Rúgolo de Agrazar et al., 2005). Based on the bioprospection carried out in this region (Troiani \& Steibel, 1999) the most relevant species selected were: Ambrosia tenuifolia, Baccharis articulata, Baccharis spartioides, Helianthus petiolaris and Senecio serratifolius.

In this context the aim of this study was to assess the repellent properties of $A$. tenuifolia, $B$. articulate, B. spartioides, $H$. petiolaris, $S$. serratifolius EOs on $T$. castaneum and find a blend that allows its future application in store grains.

\section{Material and Methods}

\section{Plant materials}

The aerial parts of $A$. tenuifolia, $B$. articulata, B. spartioides, $H$. petiolaris and $S$. 
serratifolius were collected from different locations of La Pampa (Argentina) from September 2013 to December 2013, during the flowering period. Plants were identified at the Botany Department, University of La Pampa. Plant material (biomass) was dried in the lab for 7 days at room temperature $\left(25-28^{\circ} \mathrm{C}\right)$.

\section{Essential oil extraction}

The EOs were extracted by hydrodestillation from the dried plant biomass by using a bench top scale extractor (Figmay SRL, Argentina). The extraction conditions were: $1 \mathrm{Kg}$ of powdered biomass, 51 water volume, $4 \mathrm{~h}$ distillation. Anhydrous sodium sulphate was used to remove water traces in EOs after extraction. Yield was calculated and extracted oils were stored at $4{ }^{\circ} \mathrm{C}$ in fulfilled, tightly closed amber flasks until analyzed and tested

\section{Insects}

T. castaneum especimens were obtained from the Center for Pest and Insecticide Research (CIPEIN-CITEFA), National University of General San Martín, Argentina. The strain was kept in plastic containers (3 1) covered with a nylon mesh. Insects were raised on wheat flour mixed with brewer's yeast $(7: 1$ $\mathrm{w} / \mathrm{w}$ ) in a growth incubator at $25-27^{\circ} \mathrm{C}$, relative humidity of $70-75 \%$ and $12: 12 \mathrm{~h}$ light:dark photoperiod.

\section{Repellent bioassay}

The Area Preference Method (Zhe Zhang et al., 2017) was followed for the evaluation of repellent activities of the essential oils extracted on $T$. castaneum. Filter papers (Whatman $\mathrm{N}^{\circ} 1$, diameter $9 \mathrm{~cm}$ ) were divided into halves. One half was impregnated with 0.5 $\mathrm{ml}$ of acetonic solution of EOs and the other half was impregnated with $0.5 \mathrm{ml}$ of acetone (control). The concentrations evaluated were $3 \times 10^{-3}, 3 \times 10^{-2}, 3 \times 10^{-1}, 0.31 \mathrm{mg} . \mathrm{cm}^{-2}$ for $B$. articulata, $B$. spartioides, $H$. petiolaris, $S$. serratifolius and $1.5 \times 10^{-3}, 1.5 \times 10^{-2}, 1.5 \times 10^{-1}$, $0.15 \mathrm{mg} \cdot \mathrm{cm}^{-2}$ for A. tenuifolia, different concentrations were used due to the amount of EO obtained from the destillation. Paper disks were air dried for $24 \mathrm{~h}$ until acetone evaporation, and then placed into a plastic petri dishes. Ten adult of $T$. castaneum were released in the middle of each disk and covered with plastic tape. The test was carried out under the same environmental conditions of temperature, humidity and photoperiod described for the raising and the plates were rotated every day to avoid basal behavior of the insects. The number of insects on each half of the paper disks was recorded every hour for $5 \mathrm{~h}$ and at $24 \mathrm{~h}$ from the beginning of the test. DEET (N, N-diethyl3-methylbenzamide from Sigma-Aldrich) was used as a positive control and a vehicle control with $0.5 \mathrm{ml}$ acetone was also set up, with the other half of the filter paper left untreated. Five replicates were used for each treatment and the experiment was repeated twice.

Percentage of repellency (PR) was calculated as follows: $\mathrm{PR}=(\mathrm{C}-\mathrm{T}) /(\mathrm{C}+\mathrm{T}) \times 100$, where $\mathrm{C}$ represent the number of insects on the untreated area, and $\mathrm{T}$ the number of insects on the treated area (Nerio et al., 2009). According to the averages PR, EOs dilutions were then assigned to different classes from 0 to $\mathrm{V}$ : class $0(0-0.1 \%)$, class I $(0.1-20 \%)$, class II (20.1$40 \%)$, class III $(40.1-60 \%)$, class IV (60.1$80 \%$ ) and class V (80.1-100\%) (Liu \& Ho, 1999).

\section{GC-MS analysis of the EOS}

Once selected the most promising EOs, they were analyzed by GC-MS in order to determine their chemical composition, and eventually the main compound responsible for the repellence. So, B. spartioides and H. petiolaris EOs were analyzed in a HP 6890N Series Plus gas chromatograph (Agilent Technologies, Palo Alto, California, USA), equipped whit a model $5973 \mathrm{~N}$ mass selective detector (Agilent Technologies, Palo Alto, California, USA) and an HP 6890 Series autoinjector. The separation of the analytes was achieved using a HP-5 MS capillary column $(30 \mathrm{~m}$ x $0.25 \mathrm{~mm}$ I.D., 0.25 $\mathrm{m}$ film thicknees and $5 \%$ phenylmethylsiloxane), supplied by J \& W Scientific (Folsom, CA, USA). Carrier gas (helium) was set at a constant flow rate. The volume of injection was $2 \mu 1$ on splitless mode, the injection port and transfer line temperatures were set at $250^{\circ} \mathrm{C}$ and $280^{\circ} \mathrm{C}$, respectively. The mass spectrometer was operated whit a 
filament current of $300 \mathrm{~mA}$ and electron energy $70 \mathrm{eV}$ in the positive electron ionization mode. Based on the mass scan range of $50-550$ atomic mass units (amu) with SCAN mode, retention times of the compounds were determined by comparing the MS fragmentation pattern of the standards and the National Institute of Standards and Technology (NIST) 2.0 GC-MS library. Chemstation Version D.01.00 was used for data acquisition, data processing, and instrument control.

\section{Repellent activity in treated flour}

According to Mohan and Fields (2002), movement of insects in the treated grains revealed the interaction between repellent and attractant abilities. In this way, a cup bioassay was conducted with minimal modifications. The best repellent concentrations previously obtain of $B$. spartioides and $H$. petiolaris EOs $\left(3 \times 10^{-1} \mathrm{mg} . \mathrm{cm}^{-2}\right)$ were used for this test. Briefly, $0.5 \mathrm{~g}$ of flour spiked with the essential oil dilution in acetone and $0.5 \mathrm{~g}$ of flour spiked with acetone (vehicle) were placed on each half of a petri dish. After air-drying the acetone, 15 larvae of $T$. castaneum were released in the middle of each container. The test was carried out under the same environmental conditions described for the rising. The number of the larvae which run away from the treatment flour was counted at two different intervals, $2 \mathrm{~h}$ and $24 \mathrm{~h}$. Three replicates were used and the experiment was repeated twice. The repellency percentage was calculated with the same equation used in repellent activity assay.

\section{Repellent activity of blends}

In order to enhance the repellent effect of the $B$. spartioides and H. petiolaris EOs and maximize the production, the different EOs were blend $50 / 50$ on a base of lemon EO (minimum limonene content $85 \%$ ) purchased from Pico esenciales.
Drugstore SA, La Pampa, Argentina. The final concentration obtained was $10 \mathrm{mg} \cdot \mathrm{ml}^{-1}$ of each EO in a lemon EO base. Once blended, the Area Preference Method (2.4) was followed for the evaluation of repellent activities.

\section{Statistical analysis}

Data were analyzed using InfoStat software. One-way analysis of variance (ANOVA) and Tukey test were performed on the data to determine significant differences $(p<0.05)$ among concentrations for repellent activity test. The same analysis was made to find the differences in repellent activity between pure extracts and blends.

\section{Results AND Discussion}

Sufficient biomass (from 100 to $500 \mathrm{Kg}$ depending on EOs yield) of each plant species was steam-distilled to obtain $5 \mathrm{ml}$ of each EO. The EO yields of the different species are presented in Table 1 with the coordinates and locations of the site of collection. In general, the yields of the 5 essential oils extracted range from $0.001 \%$ (B. articulata and S. serratifolius) to $0.1 \%$ (B. spartioides and $H$. petiolaris). Although it is necessary to harvest a considerable amount of biomass to obtain the oil, since these species are endemic and ruderal, the collection can be done without creating damage or selective pressure on the ecosystem (Elechosa, 2009).

Results of repellency assays for the tested EOs are presented in Table 2. Tested oils showed repellent activities against $T$. castaneum in a dose-dependent manner. Except for $A$.

Table 1. Plant species, collecting information and yield of essential oils.

Tabla 1. Especies vegetales, información de colecta y rendimiento de aceites

\begin{tabular}{|c|c|c|c|c|}
\hline Species & Origin & Latitude & Longitude & $\begin{array}{c}\text { EO } \\
\text { Yield (\%w/w) }\end{array}$ \\
\hline A. tenuifolia & Santa Rosa, LP & $36^{\circ} 37^{\prime} 39.917^{\prime \prime S}$ & $64^{\circ} 18^{\prime 2} 23.949^{\prime \prime} \mathrm{W}$ & 0.05 \\
\hline B. articulata & Toay, LP & $36^{\circ} 42^{\prime} 55.011^{\prime \prime} \mathrm{S}$ & $64^{\circ} 20^{\prime} 27.788^{\prime \prime} \mathrm{W}$ & 0.001 \\
\hline B. spartioides & Puelches, LP & $37^{\circ} 52^{\prime} 26.444^{\prime \prime S}$ & $65^{\circ} 26^{\prime} 57.593$ '” & 0.1 \\
\hline H. petiolaris & Santa Rosa, LP & $36^{\circ} 37^{\prime} 8.348^{\prime \prime S}$ & $64^{\circ} 19^{\prime} 11.76 ” \mathrm{~W}$ & 0.1 \\
\hline S. serratifolius & $\begin{array}{l}\text { Int. RN N }{ }^{\circ} 5-\mathrm{RN} \\
\mathrm{N}^{\circ} 7, \mathrm{LP}\end{array}$ & $36^{\circ} 32^{\prime} 12.383^{\prime \prime S}$ & $63^{\circ} 56^{\prime} 40.017^{\prime \prime} \mathrm{W}$ & 0.001 \\
\hline
\end{tabular}

LP: La Pampa province, Argentina. RN: Nacional Route.

$\%$ w/w: gr of EO/ gr of plant material distilled 
Repellent activity of essential oils from native plants and their blend for Tribolium castaneum control in store grains

Table 2. Repellency of EOs.

Tabla 2. Repelencia de los EOs

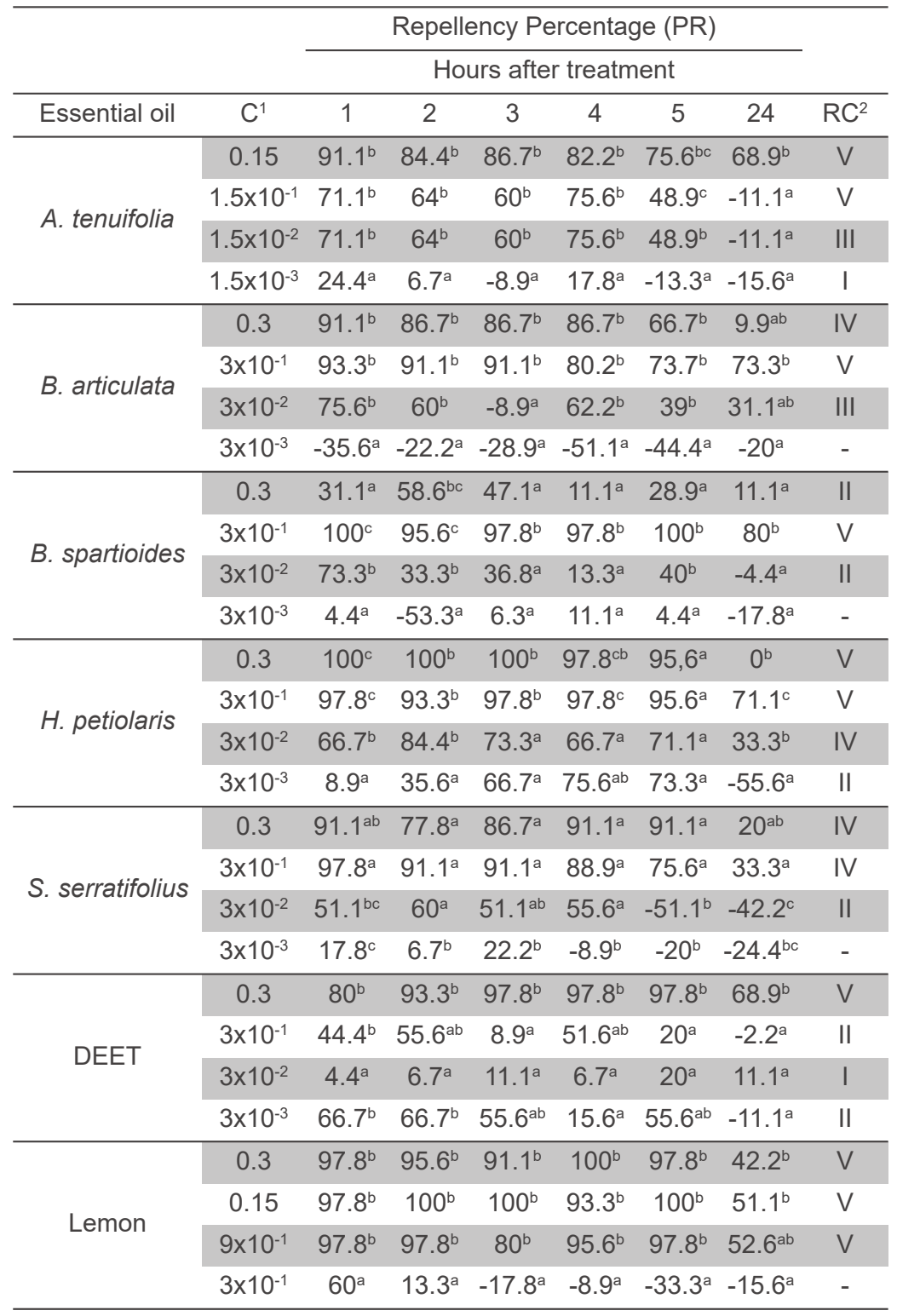

$\mathrm{C}^{1}$ : concentration $\left(\mathrm{mg} \cdot \mathrm{cm}^{-2}\right) ; \mathrm{RC}^{2}$ : repellency class. Means within the same column followed by the same letter are not significantly different. ANOVA, Tukey $(P>0.05)$.

tenuifolia, all plant species show higher repellency at the $3 \times 10^{-1} \mathrm{mg} \cdot \mathrm{cm}^{-2}$. In this way, Zhe Zhang et al. (2017) reported that the activity of Artemisia ordosica EOs didn't increase with the increase in the concentration on $T$. castaneum. In addition, it was observed that the repellency activity of all species have a fluctuating behavior in the first $5 \mathrm{~h}$, decreasing before $24 \mathrm{~h}$ of exposure. B. spartioides EO presented the strongest repellent activity against T. castaneum at $3 \times 10^{-1} \mathrm{mg} \cdot \mathrm{cm}^{-2}$, class $\mathrm{V}$ of repellent. H. petiolaris $\mathrm{EO}$ was the second most effective, showing its maximum repellent activity at the same concentration, also class $\mathrm{V}$ of repellent. Both oils exhibited higher repellent activity than the positive control DEET (class II) at this concentration. At the lowest assayed dose $\left(3 \times 10^{-3} \mathrm{mg} \cdot \mathrm{cm}^{-2}\right)$, only $H$. petiolaris showed moderate repellency (class II). However, all EOs were under DEET repellency (class II). Comparing the percentage of repellency obtained at different concentrations, significant differences were observed in the third dilution $\left(3 \times 10^{-2}\right.$ $\mathrm{mg} . \mathrm{cm}^{-2}$ ) in $50 \%$ of the samples.

In the best of our knowledge, this is the first report of repellent activity on T. castaneum for the EOs of A. tenuifolia, B. articulata, H. petiolaris and Senecio serratifolius. For $B$. spartioides, Jofré Barud et al. (2014) reported repellent activity of the pure essential oil against the fruit fly pest, Ceratitis capitata and it was reported too it antimicrobial (Oliva et al., 2007) and nematicidal (Sosa et al., 2012) activity. There were also some reports about EO from other Baccharis species, such as $B$. salicifolia and $B$. darwinii, possessing great repellent activity against insects and plantparasites nematodes (Sosa et al., 2012; Kurdelas et al., 2012).

The results of GC-MS analysis of $B$. spartioides and $H$. petiolaris EOs are shown in Table 3. In B. spartioides EO, 5 major compounds were identified, which represented 
Saran, A., Fernández, L., Minig, M., Bellozas Reinhard, M., y Merini, L.J.

Table 3. Identification of constituents present in $B$. spartioides and $H$. petilaris EOs.

Tabla 3. Identificación de los constituyentes presentes en los EOs de $B$. spartioides y $H$. petilaris.

\begin{tabular}{clcc} 
Rt (min) & \multicolumn{1}{c}{ Compounds } & $\begin{array}{c}\text { B. } \\
\text { spartiodes }\end{array}$ & $\begin{array}{c}H . \\
\text { petiolaris }\end{array}$ \\
\hline 7.134 & (S) cisVerbenol & - & 12.54 \\
8.143 & Verbrnone & - & 6.08 \\
7.301 & Verbenol & - & 10.79 \\
8.950 & Bornyl acetate & - & 18.97 \\
13.187 & a-Bisabolol & - & 5.53 \\
14.135 & Ledene oxide (I) & 35.15 & - \\
14.068 & Spathulenol & - & 5.53 \\
14.135 & Ledene oxide (I) & 31.1 & 27 \\
\hline 14.719 & Caryophyllene oxide & - & 3.53 \\
\hline 16.438 & Isoaromadendrene & & \\
\hline & 1,6(1-(Hydroxymethyl)vinyl)- & 6.42 & - \\
16.863 & $4,8 a-d i m e t h y l-3,5,6,7,8,8 a-$ \\
& hexahydro-2(1H)-naphthalenone & & \\
\hline 19.132 & a-Pipene oxide & 20.74 & 3.56 \\
\hline 24.538 & Manoyl oxide & - & 1 \\
\hline Total & & 94.73 & 89 \\
\hline $\mathrm{Ni}$ & & 5.27 & 11
\end{tabular}

Values are expressed as relative percentages and compounds are listed by elution order according to GC-MS analyses

Ni: Not identified

about $95 \%$ of the total composition. The main compounds identified (concentrations higher than 30\%) were Spathulenol (35.15\%) and Caryophyllene oxide (31.10\%). Jofré Barud et al., (2014) reported that the composition of $B$. spartioides EO from San Juan province was dominated by the monoterpene hydrocarbons, $\alpha$ phellandrene (44.5\%), sabinene $(20.7 \%)$ and $\alpha$ pinene (15.9\%). In contrast, Oliva et al., (2007) reported the composition of $B$. spartioides from three populations of Argentina (Northwest, Central and Patagonia areas were the main constituents of the oils were camphor (26.5$50 \%$ ), limonene (4.3-35.8\%), citronellal (12\%), carvone $(10 \%)$ and spathulenol (2.1-11.8\%), finding a relatively high variation in their composition and antimicrobial activity depending on the origin. Such divergence in results reveals the intrinsic variability of the EOs composition depending on the complex interaction between plant phenotype and environment. In addition, other sources of compositional variability can also include the part of the plant extracted, the phenological state of the plant and time of year (Isman \& Machial, 2006). In this context, EOs composition predictability is one of the main biotechnological challenges in bioformulated production and identifying the responsible for repellence as well as toxic compounds is critical (Canter et al., 2005).

In $H$. petiolaris EO, 9 major compounds were identified, which represent about $90 \%$ of the total composition. All components that represented more than $1 \%$ in composition are listed, being the major compounds (concentrations higher than 12\%) the (S) cisVerbenol (12.54\%) and Caryophyllene oxide $(27.00 \%)$. As far as we know, this report constitutes the first description of the $H$. petiolaris essential oil composition by GCMS analysis.

The results of the repellent activity assay performed in treated flour are presented in Table 4. In the case of $H$. petiolaris EO, 90\% of the insects rejected the treated flour while $B$. spartioides induced $67.6 \%$ of emigration. In both cases, the repellency decreased after 24 hours of treatment in about 20 and $25 \%$, respectively.

Sadeghi et al. (2013) reported the repellency of Palizin ${ }^{\circledR}$ (Coconut Soap 65\%) on $T$. castaneum and others stored product pest using the cup bioassay as a method that simulates complexity of real condition in repellent activity, crop and pest behavior. Silva et al. (2002) reported that the effect of most plants used in pest control, more than being insecticidal are insectistatic (growth regulators) because they inhibit normal development of insects. In this way, the application of sub-lethal doses of natural products, or even chemical pesticides as a new pest control approach has become more common nowadays. This is particularly relevant

Table 4. Repellent activity of treated flour with $B$. spartioides and $H$. petiolaris EOs.

Tabla 4. Actividad repelente de harina tratada con los EOs de $B$. spartioides y $H$. petiolaris.

\begin{tabular}{lccc}
\hline Essential oil & $\begin{array}{c}\text { concentration } \\
(\mathrm{mg} / \mathrm{cm} 2)\end{array}$ & $\mathrm{PR}^{2} 2 \mathrm{~h}$ & $\mathrm{PR}^{2} 24 \mathrm{~h}$ \\
\hline B. spartioides & $3 \times 10^{-1}$ & 95.5 & 67.6 \\
H. petiolaris & $3 \times 10^{-1}$ & 100 & 80 \\
\hline
\end{tabular}


in a context where the use of broadly toxic chemical pesticides is now under serious restrictions in an increasingly regulated world. This pest control strategy has become crucial in the case of insects in stored grain, since the accumulation of toxic residues in food products is strictly scrutinized and matter of public concern.

Fumigant activity was also assayed but the concentration of EOs tested $\left(3 \times 10^{-1} \mathrm{mg} . \mathrm{cm}^{-2}\right)$ result not lethal against $T$. castaneum (data not shown). More studies must be undertaken to elucidate the differences found between the repellent and fumigant activity but a possible

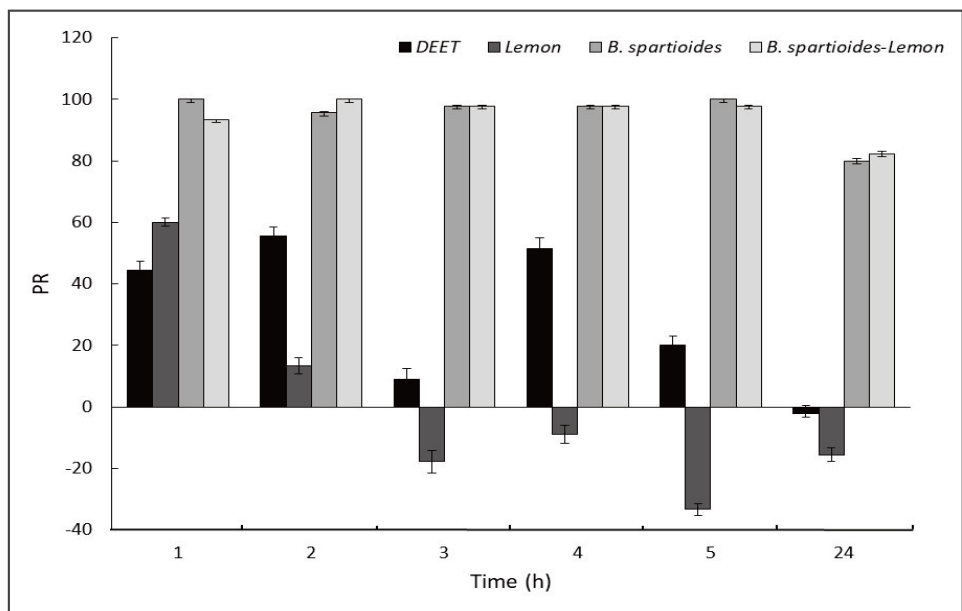

Figure 1. Repellency activity for the blend proposed B. spartioides-Lemon, compared with pure EOs and DEET at $3 \times 10^{-1} \mathrm{mg}_{\mathrm{cm}} \mathrm{cm}^{-2}$ of concentration.

Figura 1. Actividad repelente de la mezcla propuesta $B$. spartioides-Lemon, comparada con los EOs puros y DEET a $3 \times 10^{-1} \mathrm{mg} \cdot \mathrm{cm}^{-2}$ de concentración

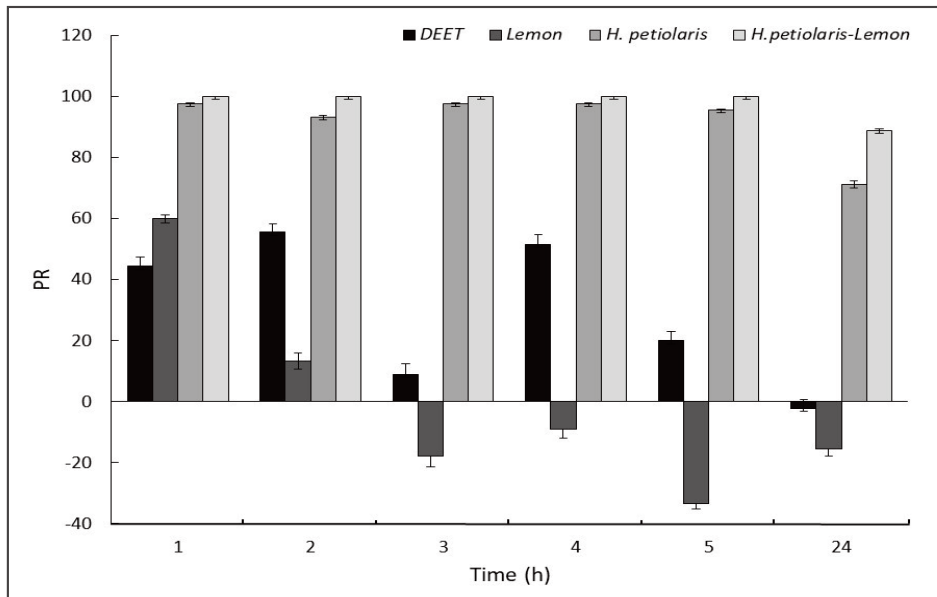

Figure 2. Repellency activity for the blend proposed $H$. petiolaris-Lemon, compared with pure EOs and DEET at $3 \times 10^{-1} \mathrm{mg}^{-\mathrm{cm}^{-2}}$ of concentration.

Figura 2. Actividad repelente de la mezcla propuesta $H$. petiolaris-Lemon, comparada con los EOs puros y DEET a $3 \times 10^{-1} \mathrm{mg} \cdot \mathrm{cm}^{-2} \mathrm{de}$ concentración. explanation could be based on the respiration rates of T. castaneum (Emekci et al., 2002). Benzi et al., (2014) reported fumigant activities o South American plants against the stored staneum.

ults of repellency activity for the posed are presented in Figure 1 and treatment while the pure $\mathrm{EO}$ of $H$. petiolaris the same period. In the case of $B$. spartioides-Lemon blend (Figure 1), both the blend and the pure EO of $B$. spartioides decreased in a $20 \%$. When the pure lemon EO was used at the concentration of $3 \times 10^{-1} \mathrm{mg} . \mathrm{cm}^{-2}$, it did not show any repellency activity, however when it was used in combination with $H$. petiolaris EO, the blend increased by $20 \%$ its repellency at $24 \mathrm{~h}$ of treatment. Although the concentration to generate the repellent effect is high compared to the yield of the oil of this species, the proposed blend reduces by half the concentration of oil needed and in turn increases the repellent effect over time.

Lee et al., (2002) reported the fumigant toxicity of lemon oil against $T$. castaneum obtaining the second most potent activity (LD50 $=16.2 \mu 1.1^{-1}$ air). Besides Karamaouna et al., 2013 informed that in range from 2.7 to 8.1 mg. $\mathrm{mL}^{-1}$ of concentration Citrus limon L. peel EOs (mainly limonene) were the most toxic of all the tested EOs, against the vine mealybug. We found that in a range from 30 to $100 \mathrm{mg} \cdot \mathrm{ml}^{-1}$ of concentration Lemon EO is classified as class $\mathrm{V}$ repellency against adults of $T$. castaneum (Table 2). Also limonene was 
registered as a pesticide active ingredient in 15 products: for use against ticks and fleas, as an insecticide spray, as an outdoor dog and cat repellent, as a by repellent on tablecloths, as an insect repellent for use on humans, and as a mosquito larvicide (EPA, 1994). At least one U.S. patent ( $\mathrm{N}^{\circ}$ 5.653.991 published in 1997 by Robert L. Rod; USPTO 1997) refers to the use of various oil-based formulations of d-limonene, with or without a water carrier, against plant pests such as whitefies.

Essential oils are complex mixtures of numerous molecules and their bioactivity could be affected by interactions among their structural components due to additive action and/or synergism between chemical classes (Hummelbrunner \& Isman, 2001). The activity of the main components could also be modulated by other minor molecules (Franzios et al., 1997).

These findings present the $B$. spartioides and $H$. petiolaris EOs blend as promising alternatives to control $T$. castaneum in stored grains, as safer and more suitable substitutes of the synthetic insecticides currently used

\section{Conclusions}

Bioprospecting for less toxic and environmental friendly bio-products as substitutes in stored grain protection is raising research area, and native species are a promising reservoir.

In this context, the use of the EOs extracted from these five plant species could be proposed as a new botanical insecticide, since they are able to control the pest $T$. castaneum at doses 10 times lower than standard synthetic products used nowadays (DEET). However, based on the persistence of repellency and its low production cost, we recommend the blend of the $B$. spartioides and $H$. petiolaris EOs, with a base of lemon EO, as the best bio-product. Additional trials are needed to comprehensively assess toxicity, evaluate the effect of this blend and validate their efficacy under conditions of large scale grain storage

\section{ACKNOWLEDgementS}

This document has been produced with the financial support of FONTAGRO (The opinions in this publication are exclusively those of the authors and do not reflect the point of view of FONTAGRO, its Board of Directors, the Bank, its Sponsoring Institutions, or the countries they represent). This study was also supported by the National University of La Pampa, through the projects "Bioactive natural products using native species and introduced in the Pampean semi-arid region" Resolution $\mathrm{N}^{\circ} 240 / 14$ and "Plant extracts of possible insecticide use, of species of the family Asteraceae, native and introduced in the Province of La Pampa" Resolution N 117.

\section{REFERENCES}

Alonso Amelot, M. E., \& Avila Núñez, J. L. (2011). Comparison of seven methods for stored cereal losses to insects for their application in rural conditions. Journal of Stored Products Research, 47, 82-87.

Bakkali, F., Averbeck, S., Averbeck, D., \& Idaomar, M. (2008). Biological effects of essential oils review. Food and Chemical Toxicology, 46, 446-475.

Batish, D. R., Singh, H. P., Kohli, K. R., \& Kaur, S. (2008). Eucalyptus essential oil as a natural pesticide. Forest Ecology and Management, 256, 2166-2174.

Benzi, V., Stefanazzi, N., Murray, A. P., Werdin González, J. O., \& Ferrero, A. (2014). Composition, Repellent, and Insecticidal Activities of Two South American Plants against the Stored Grain Pests Tribolium castaneum and Tribolium confusum (Coleoptera: Tenebrionidae). Hindawi Publishing Corporation. Entomology, 14.

Canter, P. H., Thomas, H., \& Ernst, E. (2005). Bringing medicinal plants into cultivation: opportunities and challenges for biotechnology. Trends in Biotechnology, 23, 180-185.

Descamps, L. R., Stefanazzi, N., Sanchez Chopa, C., y Ferrero, A. A. (2008). Actividad biológica de extractos vegetales de Schinus molle var. areira (Anacardiaceae) en Tribolium castaneum Herbst. (Insecta, Coleoptera, Tenebrionidae), plaga de grano almacenado. Boletín de la Sanidad VegetalPlagas, 34, 595-605.

Elechosa, M. A. (2009). Manual de recolección sustentable de plantas aromáticas nativas de la región central y noroeste de la Argentina. INTA. 633.8.

[EPA] U.S. Environmental Protection Agency. 1994. Reregistration eligibility decision (RED): limonene. EPA 738-R-94-034. U.S. Environmental Protection Agency, Office of Prevention, Pesticides and Toxic Substances, Washington, DC.

Emekci, M., Navarro, S., Donahaye, E., Rindner, M., \& Azrieli, A. (2002). Respiration of Tribolium castaneum (Herbst) at reduced oxygen concentrations. Journal of Stored Products Research, 38, 413-425.

FAO. (2013). United Nations Organization for Food and Agriculture. Maximum Codex limits for pesticide residues. Published on the Internet, available at http://www.fao.org/waicent/faostat/Pest- 
Residue/pest-s.htm.

Fisher, K., \& Phillips, C. (2008). Potential antimicrobial uses of essential oils in food: is citrus the answer? Trends in Food Science and Technology, 19, 156164.

Franzios, G., Mirotsou, M., Hatziapostolou, E., Kral, J., Scouras, Z., \& Mavragani-Tsipidou, P. (1997). Insecticidal and genotoxic activities of mint essential oils. Journal of Agricultural and Food Chemistry, 45, 2690-2694.

Giuliano, D. A. (2001). Clasificación infragenérica de las especies argentinas de Baccharis (Asteraceae, Astereae). Darwiniana, 39, 131-154.

Hummelbrunner, L., \& Isman, M. (2001). Acute, sublethal, antifeedant, and synergis-tic effects of monoterpenoid essential oil compounds on the tobacco cutworm, Spodoptera litura (Lep.: Noctuidae). Journal of Agricultural and Food Chemistry, 49, 715-720.

INTA. (2008). Postharvest efficiency: generation, development and diffusion of technologies to increase the efficiency of conditioning, drying and storage of cereals, oilseeds and industrial crops in the country. Available at: http://agrolluvia.com/wpcontent/uploads/2010/01/inta-balcarce-proyectoespecifico-eficiencia-de-poscosecha_pdf

Isman, M. B., \& Machial, C. M. (2006). Pesticides based on plant essential oils fromtraditional practice to commercialization. In: Rai, Carpinella (Eds.), NaturallyOccurring Bioactive Compounds. Elsevier Publishing Co., pp. 29-44.

Jeffrey, C. (2007). Compositae: Introduction with key to tribes. Families and Genera of Vascular Plants, VIII: 61-87.

Jindal, V., Dhaliwal, G. S., \& Koul, O. (2013). Pest management in 21st century: roadmap for future. Biopesticides International, 9, 1-22.

Jofré Barud, F., López, S., Tapia, A., Feresina, G. E., \& López, M. L. (2014). Attractant, sexual competitiveness enhancing andtoxicactivities of the essentialoilsfrom Baccharis spartioides and Schinus polygama on Ceratitis capitata Wiedemann. Industrial Crops and Products, 62, 299-304.

Karamaouna, F., Kimbaris, A., Michaelakis, A., Papachristos, D., Polissiou, M., Papatsakona, P., \& Tsora, E. (2013). Insecticidal activity of plant essential oils against the vine mealybug, Planococcusficus. Journal of Insect Science, 13, 142.

Kurdelas, R. R., López, S., Lima, B., Egly Feresin, G., Zygadloc, J., Zacchino, S., López, M. L., Tapia, A., \& Freilea, M. L. (2012). Chemical composition, anti-insect and antimicrobial activity of Baccharis darwinii essential oil from Argentina, Patagonia. Industrial Crops and Products, 40, 261-267.

Lee, B., Lee, S., Annis, P. C., Pratt, S. J., Park, B., \& Tumaalii, F. (2002). Fumigation toxicity of essential oils, monoterpenes against the red flour beetle, Tribolium castaneum Herbst. Journal Asia-Pacific Entomology, 5, 237-240.

Liu, Z. L., \& Ho, S. H. (1999). Bioactivity of the essential oil extracted from Evodia rutaecarpa Hook f. et Thomas against the grain storage insects, Sitophilus zeamais Motsch. and Tribolium castaneum (Herbst). Journal of Stored Products Research, 35, 317-328.

Mohan, S., \& Fields P. G. (2002). A simple technique to assess compounds that are repellent or attractive to stored product insects. Journal of Stored Products Research, 38, 23-31.

Nerio, L., Olivero Verbel, J., \& Stashenko, E. (2009). Repellency activity of essential oils from seven aromatic plants grown in Colombia against Sitophilus zeamais Motschulsky (Coleoptera). Journal of Stored Products Research, 45, 212-214.

Oliva, M. M., Zunino, M. P., López, M. L., Soria, Y. A., Ybarra, F. N., Sabini, L., Demo, M. S., Biurrun, F., \& Zygadl, J. A. (2007). Variation in the essential oil composition and antimicrobial activityof Baccharis spartioides $(\mathrm{H}$. etA) J. Rimy from three regions of Argentina. Journal of Essential Oil Research, 19, 509-513.

Padın, S., Dal Bello, G., \& Fabrizio, M. (2002). Grain loss caused by Tribolium castaneum, Sitophilus oryzae and Acanthos celidesobtectus in stored durum wheat and beans treated with Beauveria bassiana. Journal of Stored Products Research, 38, 69-74.

Rees, D., 2004. Insects of Stored products. CSIRO. Australia. $181 \mathrm{pp}$.

Regnault Roger, C., Vincent, C., \& Arnason, J. T. (2012). Essential oils in insect control: low-risk products in a high-stakes world. Annual Review of Entomology, 57, 405-424.

Rúgolo de Agrazar, Z. E., Steibel, P. E., y Troiani, H. O. (2005). Manual ilustrado de las gramíneas de la provincia de La Pampa. Primera Edición. Argentina, La Pampa: Editorial 25 de la Universidad Nacional de La Pampa; Córdoba, Río Cuarto: Editorial de la Universidad de Río Cuarto.

Ruiz Leal, A. (1975). Flora popular mendocina. Argentina, Buenos Aires: Eudeba.

SENASA. (2013). National Secretariat of Agricultural Health. Plant Protection, Agrochemicals. Published on the Internet, available at http://www.senasa.gov.ar.

Silva, G., Lagunes, A., Rodríguez, J., y Rodríguez, D. (2002). Insecticidas vegetales: unavieja y nueva alternativa para el manejo de plagas. Manejo Integrado de Plagasy Agroecología, 66, 4-12.

Sosa, M. E., H.G. Lancelle, C. E. Tonn, M. F. Andres, A. Gonzalez, Coloma. (2012). Insecticidal and nematicidal essential oils from Argentinean Eupatorium and Baccharis spp. Biochemical Systematics and Ecology, 43, 132-138.

Subramanyam, B., \& Hagstrum, D. W. (1995). Resistance measurement and management. In: Integrated managments of insects in stored products. 1, 331-339.

Troiani, H. O., y Steibel, P. H. (1999). Sinopsis de las Compuestas (Compositae Giseke) de la provincia de La Pampa, Rep. Argentina. Revista de la Facultad de Agronomía UNLPam, 10(1), 1-90.

Zhe, Z., Shan-shan, G., Wen-juan, Z., Zhu-feng, G., Junyu, L., Shu-shan, D., Cheng-fang, W., \& Zhi-wei, D. (2017). Essential oil and polyacetylenes from Artemisia ordosica and their bioactivities against Tribolium castaneum Herbst (Coleoptera: Tenebrionidae). Industrial Crops and Products, $100,132-137$ 